\title{
PENGGUNAAN PETA KONSEP UNTUK MENINGKATKAN KEMAMPUAN LOGIKA PEMBUKTIAN MAHASISWA
}

\author{
Vivi Suwanti \\ Universitas Kanjuruhan Malang \\ vivi_devbatghost@yahoo.com
}

\begin{abstract}
Abstrak
Dalam pembelajaran Struktur Aljabar 1 mahasiswa seringkali menemui kesulitan dalam mengkonstruksi bukti. Salah satu alasan yang menyebabkan kesulitan tersebut adalah kurangnya kemampuan logika pembuktian mahasiswa sehingga tidak dapat membuat keputusan langkah yang tepat untuk mengkonstruksi bukti. Tujuan penelitian ini adalah untuk mendeskripsikan proses penggunaan peta konsep untuk meningkatkan kemampuan logika pembuktian mahasiswa. Penelitian ini merupakan penelitian tindakan kelas. Subjek penelitian adalah 31 mahasiswa kelas 2014 D tahun ajaran 2015/2016 Pendidikan Matematika Universitas Kanjuruhan Malang. Dari hasil penelitian didapatkan, terjadi peningkatan nilai rata-rata pada siklus 1 dari 58.96 menjadi 60.5. Mahasiswa dengan nilai di atas 70 juga meningkat dari $32 \%$ menjadi 38\%. Pada siklus 2 rata-rata nilai meningkat dari 60.5 menjadi 70.1. Mahasiswa yang mendapatkan nilai di atas 70 juga meningkat menjadi 58\%. Oleh karena itu disimpulkan bahwa penggunaan peta konsep sebagai bantuan visualisasi alur logika pembuktian dapat meningkatkan kemampuan logika pembuktian mahasiswa dan memberikan respon positif dalam kegiatan belajar.
\end{abstract}

Kata kunci : pembuktian, logika, peta konsep

\begin{abstract}
When learning Algebraic Structure students often encounter difficulties in constructing a proof. One of the reasons that led to these difficulties is the lack of ability of logic verification so that students can't make appropriate decisions to make steps to construct a proof. The purpose of this study was to describe the use of concept maps to improve mathematical logic of student proofing. This study was a class action research. The subjects were 31 students of class 2014 D in Mathematics Education of Kanjuruhan Malang University. In first cycle, there are an increase in the average value from 58.96 into 60.5. Students with scores above 70 also increased from $32 \%$ to $38 \%$. In the second cycle the the average value increased from 60.5 into 70.1 and there are 58\% students who scored above 70 . It was concluded that the use of concept maps as a visualization of the logical flow of proof could increase the ability of logic verification of students and provide a positive response in learning activities.
\end{abstract}

Key word : proof, logic, concept maps

\section{PENDAHULUAN}

Pembuktian pernyataan matematis (proposisi) merupakan salah satu kegiatan pembelajaran yang hampir selalu kita temui dalam berbagai mata kuliah matematika. Pada setiap teorema, lemma, maupun akibat (corollary) yang ditemui dalam teori mata kuliah yang dipelajari pasti akan dilakukan pembuktian. Sundstrom (2014) menyatakan bahwa seorang matematikawan pasti mampu menemukan konklusi/ kesimpulan (berupa kebenaran atau kesalahan suatu proposisi) dan mengkonstruksi bukti yang valid dari konklusi tersebut. Dengan kata lain, ketika bukti dari suatu konklusi ditemukan, matematikawan akan bisa mengkomunikasikan penemuan bukti tersebut kepada pihak lain yang juga 
berbicara dalam bahasa matematis. Oleh karena itu, pembuktian memainkan suatu peran penting dalam matematika, dalam arti setiap kebenaran maupun kesalahan dari suatu proposisi atau pernyataan matematis akan didukung dengan suatu pembuktian (Buss, 1998).

Tujuan dari suatu pembuktian adalah untuk menunjukkan kevalidan dari suatu kesimpulan/konklusi dengan cara menempatkan secara bersama-sama sejumlah konklusi-konklusi lain yang lebih sederhana yang telah diketahui kevalidannya (Morris \& Morris, 2013). Untuk menempatkan konklusi-konklusi yang akan disusun dalam satu kontruksi bukti diperlukan penguasaan logika matematika. Logika diperlukan untuk memutuskan apakah suatu konklusi tertentu merupakan konsekuensi dari suatu asumsi maupun konklusi valid yang lain. Dalam hal pengkonstruksian bukti jarang ditemukan urutan penggunaan susunan konklusikonklusi yang sama dalam satu bukti dengan yang lainnya. Oleh karena itu, untuk mempelajari dan menguasai logika matematika dalam pembuktian, mahasiswa memerlukan kemampuan bernalar agar dapat memahami konsep yang terkandung dalam logika matematika dan mampu memutuskan susunan atau urutan konklusikonklusi yang akan digunakan dalam langkah-langkah pembuktian.

Menurut Longman (dalam Kaur, 2012), kemampuan bernalar adalah kemampuan untuk memikir, memahami, dan membentuk opini atau memutuskan yang berdasar pada kenyataan. Dengan kata lain, kemampuan bernalar adalah kemampuan untuk menganalisis situasi dan mengkonstruksi argument logis. Penalaran merupakan tahapan berpikir matematika tingkat tinggi, mencakup kapasitas untuk berpikir secara logis dan sistematis. Mahasiswa dikatakan mampu melakukan penalaran matematika bila mampu menggunakan penalaran pada pola dan sifat, melakukan manipulasi matematika dalam membuat generalisasi, serta menyusun bukti.

Menurut Sundstrom (2014), logika adalah sebuah metode dan prinsip-prinsip yang dapat memisahkan secara tegas antara penalaran yang tepat dengan penalaran yang tidak tepat. Penalaran dapat diartikan sebagai penarikan kesimpulan dalam sebuah argumen. Untuk dapat berpikir dengan tepat, logika menawarkan sejumlah aturan atau kaidah-kaidah yang harus diperhatikan agar kesimpulan yang diperoleh hasilnya tepat.

Struktur Aljabar 1 merupakan salah satu mata kuliah dalam bidang matematika yang melakukan banyak proses pembuktian. Pada mata kuliah Struktur Aljabar 1, mahasiswa dilatih untuk mampu melakukan proses-proses pembuktian dengan menggunakan konsep-konsep berupa aksioma, definisi, teorema, lemma, maupun akibat yang telah diberikan. Oleh karena itu, kemampuan bernalar mahasiswa perlu ditingkatkan agar mahasiswa mampu memahami dan menerapkan konsep yang diberikan sehingga proses pembelajaran dapat berjalan dengan baik.

Akan tetapi, dalam praktik sebenarnya perkuliahan Struktur Aljabar 1 yang diampu oleh peneliti, hanya mahasiswa berkemampuan tinggi yang mampu melakukan penalaran pembuktian dengan baik. Hal ini dapat dilihat dari rata-rata nilai Ujian Tengah Semester (UTS) mata kuliah 
Struktur Aljabar 1 kelas 2014 D tahun ajaran 2015-2016 yang mencapai 58.96 dimana hanya $32 \%$ mahasiswa yang memiliki nilai di atas 70 . Oleh karena itu dibutuhkan suatu alat untuk mempermudah mahasiswa dalam melatih kemampuan bernalar logika pembuktian matematika.

Dalam membelajarkan pembuktian pada mahasiswa, dosen seringkali mengalami kesulitan dalam menunjukkan alur logika yang digunakan olehnya sehingga terkonstruksi suatu bukti. Menurut Arcavi (1999), representasi visual seperti grafik dapat membantu mahasiswa lebih mudah menangkap makna dari suatu hal yang abstrak. Oleh karena itu, untuk mempermudah mahasiswa mengerti alur logika yang digunakan oleh dosen, maka dapat digunakan peta konsep sebagai visualisasi logika pembuktian dosen yang abstrak.

Menurut Novak (dalam Grevholm, 2008) peta konsep terbangun atas proposisi-proposisi pengetahuan. Titik-titik yang memuat konsep pada peta konsep harus dihubungkan satu sama lain dengan kata penghubung untuk membentuk suatu proposisi. Pada penelitian terdahulu yang dilakukan oleh Pohan (2013) disimpulkan bahwa peta konsep memberikan hasil belajar yang lebih baik dibandingkan strategi konvensional. Menurut Ismail (2013) bantuan peta konsep dalam pembelajaran dapat meningkatkan kemampuan berpikir kritis, kognitif, dan afektif. Oleh karena itu, penelitian ini bertujuan untuk mendeskripsikan proses penggunaan peta konsep untuk meningkatkan kemampuan bernalar logika pembuktian sederhana mahasiswa.

\section{METODE PENELITIAN}

Penelitian ini dilakukan karena adanya masalah kontekstual yang dialami oleh peneliti dalam proses perkuliahan Struktur Aljabar 1 yang diampuh yaitu kesulitan dalam mengajarkan mahasiswa kemampuan untuk membuktikan teoremateorema atau pun proposisi-proposisi yang digunakan dalam teori yang diberikan. Oleh karena itu, jenis penelitian ini adalah penelitian tindakan kelas (PTK). Penelitian dilaksanakan di Universitas Kanjuruhan Malang yang beralamat di Jalan S. Supriadi No. 48 Malang. Subjek penelitian adalah 31 mahasiswa kelas 2014 D Program Studi Pendidikan Matematika Universitas Kanjuruhan Malang yang tengah menempuh mata kuliah Struktur Aljabar 1 pada tahun ajaran 2015/2016. Instrumen yang digunakan dalam pengumpulan data pada penelitian ini adalah 1) lembar observasi : untuk merekam data tentang keterlaksanaan pembelajaran dan aktivitas mahasiswa yang merupakan akibat dari tindakan yang diberikan dosen selama penelitian, 2) lembar tes akhir : untuk mengukur kemampuan bernalar logika pembuktian mahasiswa dalam membuktikan proposisi-proposisi sederhana pada materi subgrub, 3) pedoman wawancara untuk mengetahui kesulitan dan hambatan yang dialami mahasiswa selama berlangsungnya pembelajaran serta respon mahasiswa terhadap proses pembelajaran.

Penelitian tindakan kelas ini mengacu pada desain penelitian tindakan kelas yang dikemukakan oleh Kemmis dan Mc Taggart (Yuliawati, dkk : 2012) yang terdiri dari tiga tahap, yaitu : (1) perencanaan, (2) tindakan dan observasi, dan (3) refleksi. 


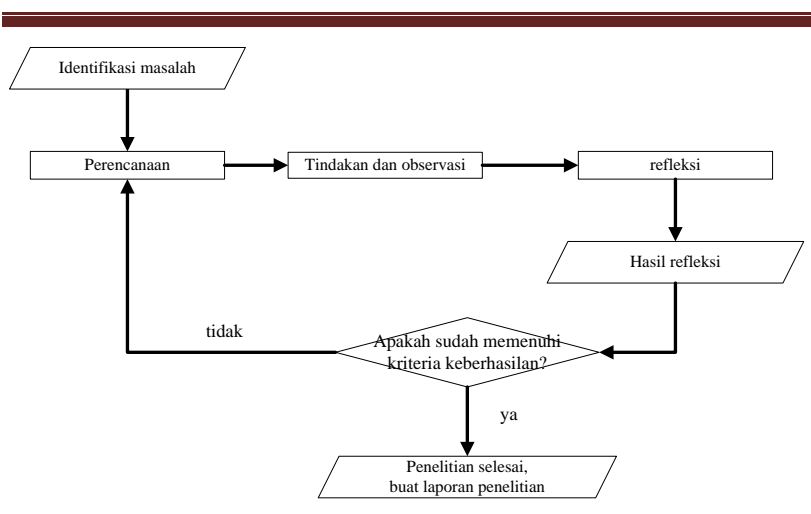

Gambar 1. Siklus penelitian

Data yang akan diambil pada penelitian ini terdiri dari dua jenis data yaitu data kualitatif dan kuantitatif. Analisis data kualitatif dilakukan selama dan setelah penelitian berlangsung dari berbagai sumber yaitu hasil kajian tes akhir, hasil wawancara, dan hasil observasi kegiatan mahasiswa. Data kuantitatif dari penelitian ini berupa skor tes akhir.

Dalam penelitian ini, kriteria keberhasilan dilihat dari hasil analisis data kualitatif dan diperkuat dengan hasil pengolahan data kuantitatif. Penelitian dikatakan berhasil jika dari hasil analisis pengerjaan tes akhir mahasiswa yang diperkuat dengan wawancara dapat disimpulkan bahwa kemampuan bernalar pembuktian mahasiswa telah meningkat. Kesimpulan ini akan didukung dengan data skor tes akhir yang menunjukkan adanya peningkatan mahasiswa yang mencapai nilai lebih dari 70 dimana pada observasi awal hanya ditemukan $32 \%$ saja dan peningkatan nilai rata-rata. Penilaian difokuskan pada aspek 1) kesesuaian pemakaian definisi, teorema, dan akibat, 2) kebenaran konsep pendukung pembuktian, dan 3) sistematis penulisan pembuktian. Soal pembuktian dibatasi pada pembuktian langsung beralur maju.

\section{HASIL DAN PEMBAHASAN}

Seperti yang telah dijelaskan pada sub bab pendahuluan, penelitian diawali dengan tahap identifikasi masalah berupa observasi hasil UTS mahasiswa. Dari wawancara tak terstruktur, diketahui bahwa, mahasiswa bisa mengerti suatu pembuktian saat dijelaskan oleh dosen akan tetapi ketika bekerja sendiri, mahasiswa mengalami kesulitan dalam mengkonstruksi bukti. Mahasiswa berkemampuan sedang dan rendah masih belum mampu menalar logika dibalik langkah-langkah yang dipilih oleh dosen. Oleh karena itu, berdasarkan hasil UTS dan pengamatan peneliti selama mengampu mata kuliah, mahasiswa dibagi menjadi 6 kelompok yang terdiri dari 5-6 mahasiswa dengan kemampuan berbeda.

Siklus 1 dilaksanakan pada Jum'at 29 april 2016 sesuai dengan jadwal perkuliahan. Pada awal siklus 1 peneliti mempersiapkan satu soal tentang pembuktian subgrub pada buku teks kuliah Struktur Aljabar 1 Elements of Modern Algebra karangan Linda \& Jimmie Gilbert. Prove ar disprove that $H=|h \in G| h^{-1}=h \mid$ is a subgroup of the group $G$ if $G$ is thelian,

Gambar 2. Soal yang digunakan peneliti sebagai contoh dalam memetakan konsep. Dari soal pada Gambar 2 dibutuhkan 3 poin yang harus dibuktikan yaitu 1) $\mathrm{H}$ tak kosong, 2) H tertutup terhadap perkalian, 3) $\mathrm{H}$ memuat invers setiap elemennya. Peneliti menjabarkan alur pembuktian menggunakan peta konsep untuk poin 1 yang dituliskan pada papan. Mahasiswa diberikan kesempatan untuk mencoba membuktikan poin 2. Selanjutnya dosen mengkonfirmasi kebenaran dari alur peta 
konsep dengan menjelaskannya di depan kelas. Hal ini diulangi lagi untuk poin 3.

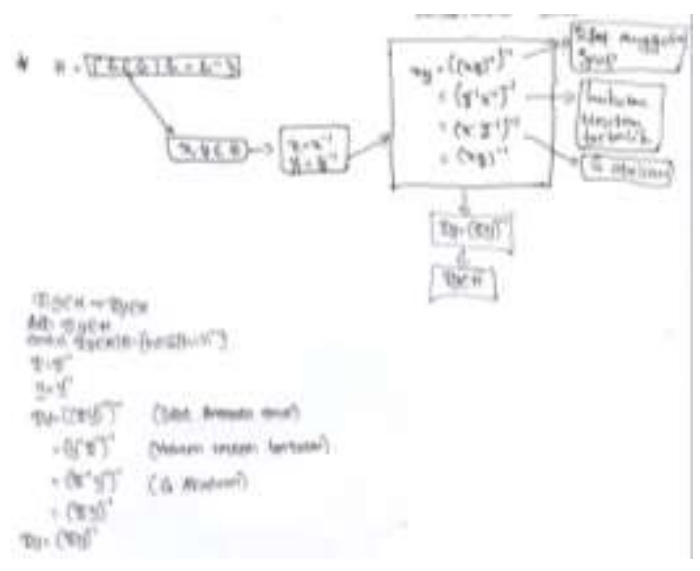

Gambar 3. Contoh peta konsep alur pembuktian dosen yang ditulis oleh mahasiswa

Siklus 1 dilaksanakan dalam 1 kali pertemuan dengan durasi 150 menit. Tes akhir siklus 1 dan wawancara dilaksanakan pada hari Sabtu 30 April 2016. Tes hanya terdiri dari 1 soal pembuktian yang sejalan dengan bahan yang dipelajari.

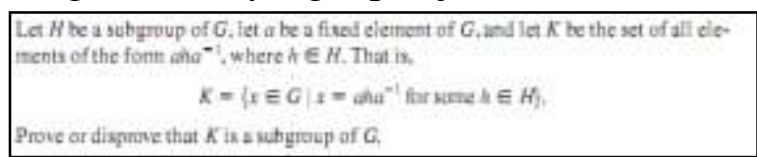

Gambar 4. Soal tes akhir siklus 1

Berdasarkan hasil pengerjaan mahasiswa pada tes akhir siklus 1 dan wawancara diketahui bahwa.

1. Peta konsep yang diajarkan oleh dosen terlalu banyak cabang sehingga membuat mahasiswa binggung. Mahasiswa belum menggubah peta konsep ke dalam bentuk narasi pembuktian.

2. Mahasiswa masih cenderung meniru peta konsep pembuktian yang dikonstruksi oleh dosen sehingga saat soal dibuat sedikit berbeda, mahasiswa sudah gagal membuat peta konsep pembuktiannya sendiri. Pada Gambar 5 terlihat bahwa AMF meniru pekerjaan dosen tanpa memahami logika dibalik langkah pembuktian. Terlihat AMF memberlakukan sifat komutatif padahal menulis keterangan asosiatif karena pada contoh yang dijelaskan oleh dosen menggunakan sifat komutatif elemen invers.

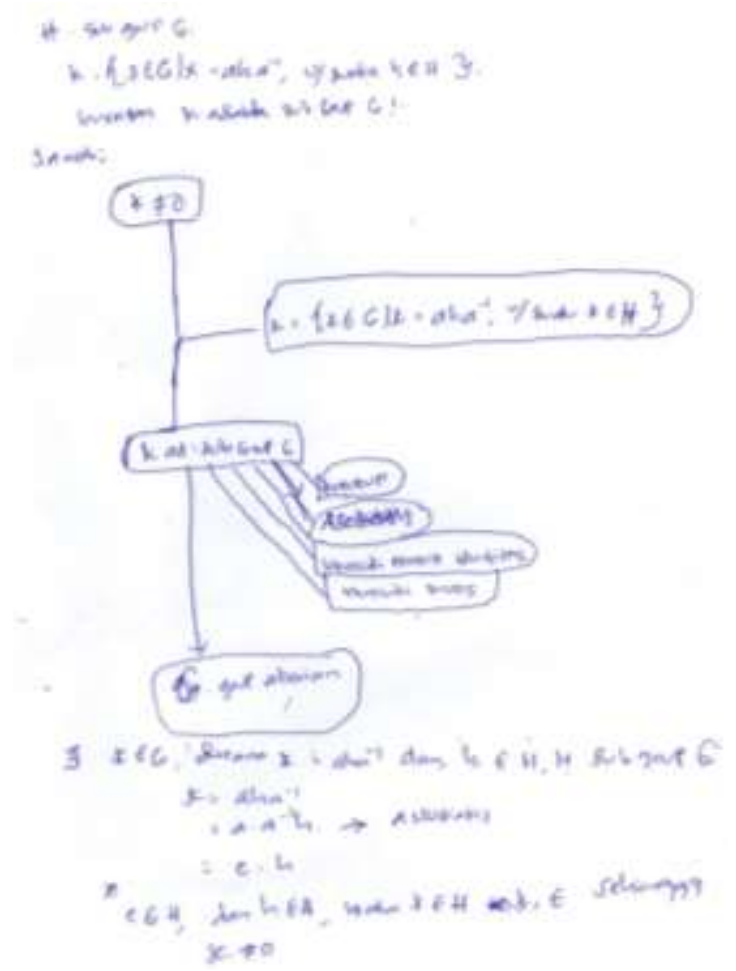

Gambar 5. Pengerjaan tes akhir siklus 1 oleh AMF yang meniru pembuktian dosen saat proses pembelajaran.

3. Adanya pemaksaan pemberlakuan sifat yang mengakibatkan pembuktian tidak valid. Secara alur sudah sesuai tetapi isi di dalam peta konsep masih salah. Mahasiswa belum bisa megubah peta konsep ke dalam bentuk narasi pembuktian yang baik. 


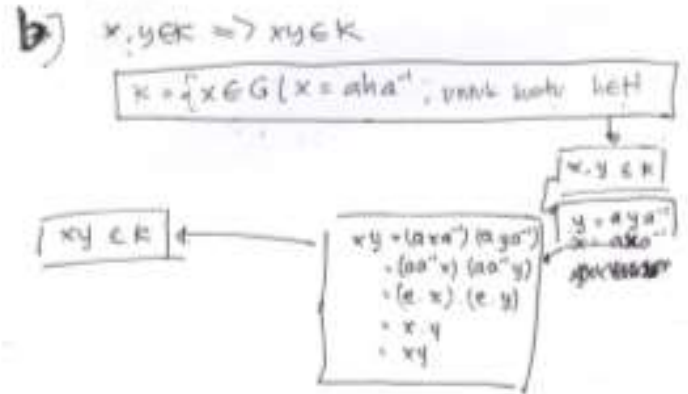

Gambar 6. Hasil kerja WK memaksakan sifat komutatif padahal tidak diketahui apakah grup komutatif atau tidak.

Rata-rata nilai tes akhir siklus mahasiswa meningkat dari 58.96 menjadi 60.5. Mahasiswa dengan nilai di atas 70 juga meningkat dari $32 \%$ menjadi $38 \%$. Meskipun hasil siklus 1 telah memenuhi kriteria keberhasilan yang ditetapkan oleh peneliti, akan tetapi peningkatan masih belum terlalu signifikan. Oleh karena itu, perlu dilakukan siklus 2 dengan beberapa refleksi berikut ini.

1. Memberikan lebih dari satu contoh alur peta konsep pembuktian yang berbeda untuk 1 soal yang sama dan membiasakan mahasiswa untuk menuliskan narasi dari peta konsep pembuktian yang telah dibuat.

2. Mereduksi titik-titik konsep yang tidak digunakan sehingga peta konsep dapat berjalan searah dan lebih sederhana.

3. Memberikan metode berfikir mundur dalam membuat peta konsep pembuktian sebagai alternatif saat mahasiswa tidak dapat berjalan maju.

4. Mengurangi terjadinya pemaksaan konsep dengan memperkuat pengetahuan awal mahasiswa mengenai materi prasyarat dengan cara memberikan banyak penekanan pada kepatuhan aturan dan sifat matematis.
Siklus 2 dilaksanakan pada Jum'at 13 mei 2016 sesuai dengan jadwal perkuliahan. Soal yang dibuktikan dengan bantuan peta konsep pada siklus 2 adalah soal tes akhir siklus 1 . Hal ini dikarenakan belum ada mahasiswa yang betul $100 \%$. Langkah-langkah pembelajaran pada siklus 2 dilakukan sesuai dengan langkah-langkah siklus 1 dengan beberapa perbaikan yang telah dijabarkan pada tahap refleksi. Siklus 2 dilaksanakan sebanyak 1 kali pertemuan dengan durasi 150 menit. Tes akhir siklus 2 dan wawancara dilaksanakan pada Sabtu 14 Mei 2016.

Berdasarkan hasil pengerjaan tes akhir siklus 2 dan wawancara yang dilakukan, disimpulkan bahwa bukti telah tertulis dalam bentuk narasi, meskipun masih terjadi pemaksaan sifat dan salah konsep awal. Berdasarkan hasil wawancara dan lembar observasi, mahasiswa merespon positif penggunaan peta konsep karena merasa lebih mudah memahami alur pembuktian. Mahasiswa menyelesaikan poin-poin pembuktian secara lengkap menggunakan langkah-langkah teorema yang sesuai meski masih terdapat beberapa kesalahan penulisan. Mahasiswa tidak terlalu terpaku dengan alur peta konsep bukti yang diberikan oleh dosen. Rata-rata nilai tes akhir siklus 2 meningkat dari 60.5 menjadi 70.1. Banyak mahasiswa yang mendapatkan nilai di atas 70 juga meningkat menjadi 58\%. Karena terjadi peningkatan nilai sesuai dengan kriteria yang telah ditetapkan maka penelitian dikatakan berhasil. 


\section{KESIMPULAN}

Penggunaan peta konsep sebagai bantuan visualisasi alur logika pembuktian dapat meningkatkan kemampuan logika pembuktian mahasiswa dengan cara menyederhanakan bentuk peta konsep, mereduksi titik-titik konsep yang tidak digunakan sehingga alur lebih jelas dan mudah dipahami mahasiswa. Jika mahasiswa menemukan hambatan dalam alur maju, maka digunakan alur mundur agar mahasiswa lebih terfokus pada tujuan pembuktian yang ingin dicapai. Kesalahan mahasiswa banyak terjadi dikarenakan kurangnya pemahaman pada materi prasyarat. Oleh karena itu, diperlukan banyak penekanan untuk mengingatkan kembali mahasiswa pada konsep prasyarat dan ketaatan aturan matematis. Penggunaan peta konsep juga menimbulkan respon positif mahasiswa karena representasi visual lebih mudah dimengerti.

\section{DAFTAR RUJUKAN}

Arcavi, A. 1999. The Role of Visual Representations in the Learning of Mathematics. Proceedings of the XXI Conference on the Psychology of Mathematics Education. North American Chapter, Mexico.

Brodie, K. 2010. Teaching Mathematical Reasoning in Secondary School Classroom. New York: Springer. 2010,hal.7.

(http://www.surfnetparents.com) Math Glossary (diakses tanggal 15 November 2015)

Buss, S. R. 1998. An introduction to proof theory. Handbook of proof theory, 137, 1-78.(http://www.math.ucsd.edu )(diakses tanggal 15 November 2015).
Grevholm, B. 2008. Concept Maps as Research Tool in Mathematics Education. In Actes du colloque CMC 2008: Third International Conference on Concept Mapping. (http://www.cmc.ihmc.us/cmc2008pape rs/cmc2008-p301.pdf )(diakses tanggal 15 November 2015).

Kaur, B., \& Toh, T. L. 2012. Reasoning, Communication and Connections in Mathematics. National Institute of Education. Singapore.

Morris, D. W., \& Morris, J. 2013. Proof And Concept :The Fundamental Abstract Of mathematics. University at Albani, State University of New York.

Sundstrom, T. 2014. Mathematical Reasoning : Writing And Proof. Grand Valley State University. Allendale.

Yuliawati, S., Jamil, M. A. 2012. Penelitian Tindakan Kelas Untuk Tenaga Pendidik Profesional. Yogyakarta: Pedagogia.

Pohan, L. A. 2013. Penggunaan Strategi Peta Konsep (Concept Mapping) Sebagai Upaya Peningkatan Hasil Belajar Kimia Siswa. Jurnal Penelitian, Penalaran, dan Pengabdian. Vol. 1 No. 1 2013. Hal 67 - 32. (online) diakses pada $25 \quad$ Januari 2016. (http://fkip.uisu.ac.id/wpcontent/uploads/2014/03/09_LisaAriyanti-Pohan-PENGGUNAANSTRATEGI-PETA-KONSEP-E1.pdf)

Ismail. 2013. Pengaruh Model Pembelajaran ARIAS dan ARIAS Dipadu Peta Konsep terhadap Kemampuan Berpikir Kritis, Kognitif, dan Afektif. Jurnal Pendidikan Sains, Vol. 1, No. 3, Hal. 284-297. (online) diakses pada tanggal 25 Januari 2016. 